\title{
Zinc Finger Protein 750
}

National Cancer Institute

\section{Source}

National Cancer Institute. Zinc Finger Protein 750. NCI Thesaurus. Code C115991.

Zinc finger protein 750 (723 aa, $77 \mathrm{kDa}$ ) is encoded by the human ZNF750 gene. This protein plays a role in transcriptional regulation that drives the development of the epidermis. 